\title{
Corrigendum to "A highly specific Escherichia coli qPCR and its comparison with existing methods for environmental waters" [Water Res. 126, 101-110]
}

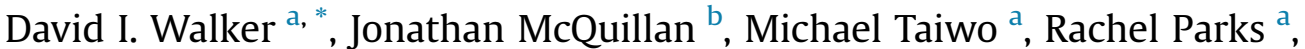 \\ Craig A. Stenton a, Hywel Morgan ${ }^{c}$, Matthew C. Mowlem ${ }^{b}$, David N. Lees ${ }^{\text {a }}$ \\ ${ }^{a}$ Centre for Environment, Fisheries and Aquaculture Science, Weymouth Laboratory, Weymouth, Dorset, UK \\ ${ }^{\mathrm{b}}$ National Oceanography Centre, Southampton, Hampshire, UK \\ ' School of Electronics and Computer Science, University of Southampton, Southampton, SO17 1BJ, UK
}

It has been brought to our attention that there is an error in the Methods, section 2.6 "Real-time PCR". The article as published states "Each reaction contained $12.5 \mu \mathrm{l}$ of IQ SYBR Supermix con- taining reaction buffer, dNTPs, Taq polymerase and SYBR Green II DNA binding dye (Biorad), $9.5 \mu \mathrm{l}$ of RT-PCR grade water (Agilent), $1 \mathrm{ml}$ of each primer (final concentration $5 \mathrm{mM}$ ) and $1 \mathrm{ml}$ of template DNA at $100 \mathrm{ng} / \mu \mathrm{l}$; the final volume was $25 \mu \mathrm{l}$. ."

However this should be "Each reaction contained $12.5 \mu \mathrm{l}$ of IQ SYBR Supermix con- taining reaction buffer, dNTPs, Taq polymerase and SYBR Green II DNA binding dye (Biorad), $9.5 \mu \mathrm{l}$ of RT-PCR grade water (Agilent), $1 \mu \mathrm{l}$ of each primer (final concentration $0.4 \mu \mathrm{M})$ and $1 \mu \mathrm{l}$ of template DNA at $100 \mathrm{ng} / \mu \mathrm{l}$; the final volume was $25 \mu \mathrm{l} . "$ 